\title{
Attributions and the Regulation of Marriage: Considering the Parallels Between Race and Homosexuality
}

E ew would dispute that religion has played a F fundamental role in shaping our understanding of human relationships, including marriage, and what types of relationships are permitted. However, science, especially biology, has also played an important role in government regulation of marriage (Bittles and Neel 1994; Ottenheimer 1990; Dupuis 2002; Ellison 2004; Strasser 2002). A cursory overview of government regulations of marriage reveals laws that establish age requirements, necessitate testing for diseases, ban nuptials between individuals with biological relations, set limits on the number of spouses, and ban interracial marriage (miscegenation), among other things (Barlow and Probert 2004; Bratt 1984; Cott 2000; Micklos and Carlson 2000; Moran 2001; Ottenheimer 1990; Scott 2000). Certainly some of these policies reflect a religious based morality, but some, such as those that

ban marriages between individuals within a

by

Donald P. Haider-Markel, University of Kansas

Mark R. Joslyn, University of Kansas family, also reflect a

biological understand-

ing of potential prob-

lems associated with

the offspring of these

couples (Bratt 1984;

Ottenheimer 1990;

Cott 2000; Micklos

and Carlson 2000; St. Jean 1998; Scott 2000; Stoddard 2003).

Not surprisingly, religious and biological understandings inform not only marriage policies, they are also central to political debates on marriage. Reflect on debate over laws banning polygamy and interracial marriage.

Polygamy opponents point to the immorality of having more than one spouse and the likely confusion over biological lineage resulting from such relationships. Likewise, proponents of bans on interracial marriage have evoked biblical support for their position and espoused racist beliefs that blacks are biologically inferior to whites (Firebaugh and Davis 1988; Micklos and Carlson 2000; Moran 2001; St. Jean 1998; Stoddard 2003; Tenzer 1990).

Consider the General Social Survey data from American adults in Figure 1. The historical pattern is evident: The percentage of adults that believe blacks have an inborn disability related to learning is strongly correlated with the percentage of adults supporting a law against interracial marriage (Pearson $\mathrm{r}=.96$, $\mathrm{p}<.000$ ). People's attributions about the biology of blacks are clearly powerful antecedents of interracial marriage policies.
Biological attributions also appear to shape contemporary debate about same-sex marriage. Figure 2, developed from Gallup surveys of national adults, illustrates the historical pattern for attributions about the origins of homosexuality and support for same-sex marriage. Identical to biological attributions about blacks, the linkage between biological based attributions about homosexuality ("gays and lesbians are born that way") and support for same-sex marriage policies is very strong (Pearson $\mathrm{r}=.95, \mathrm{p}<.000)$. The aggregate data in Figures 1 and 2 are indeed compelling and emphasize the significance of individual biological attributions of specific groups and their connection to marriage policies. Perhaps this phenomenon is not surprising given our traditional biological expectations and arguments concerning the centrality of marriage in creating and maintaining families, and in serving as the basic organizational unit in society (Barlow and Probert 2004; Cott 2000; Moran 2001; St. Jean 1998; Scott 2000). Although studies concerning theoretical and legal parallels underpinning the debates over interracial and same-sex marriages do exist (for example, see Cruz 2003), empirical research has overlooked a linkage based on biological attributions.

In this article, we examine the parallels between interracial marriage and same-sex marriage by exploring the nexus between biological attributions about blacks and homosexuals and subsequent individual preferences toward marriage policy. We find a strong individual level association between genetic or biological attributions and individual preferences about marriage policy.

\section{Beliefs about Marriage, Homosexuality, and Race}

The 2004 election campaigns clearly placed marriage on the political agenda. Nevertheless, the regulation of marriage tends to be a lowsalience issue in American politics and is generally discussed in broad symbolic terms such as "traditional values." Even without a high level of salience, the public maintains relatively strong preferences about marriage regulations; this is particularly evident for laws regulating same-sex and interracial marriages (Barlow and Probert 2004; Bowman et al. 2004; Firebaugh and Davis 1988; Kuklinski and Cobb 1998; Moran 2001; Quillian 1996; St. Jean 1998; Schuman et al. 1997). Indeed, in 2000, just over $40 \%$ of voters in Alabama rejected the 


\section{Biological Attributions About Race and Support for Laws Banning Interracial Marriage}

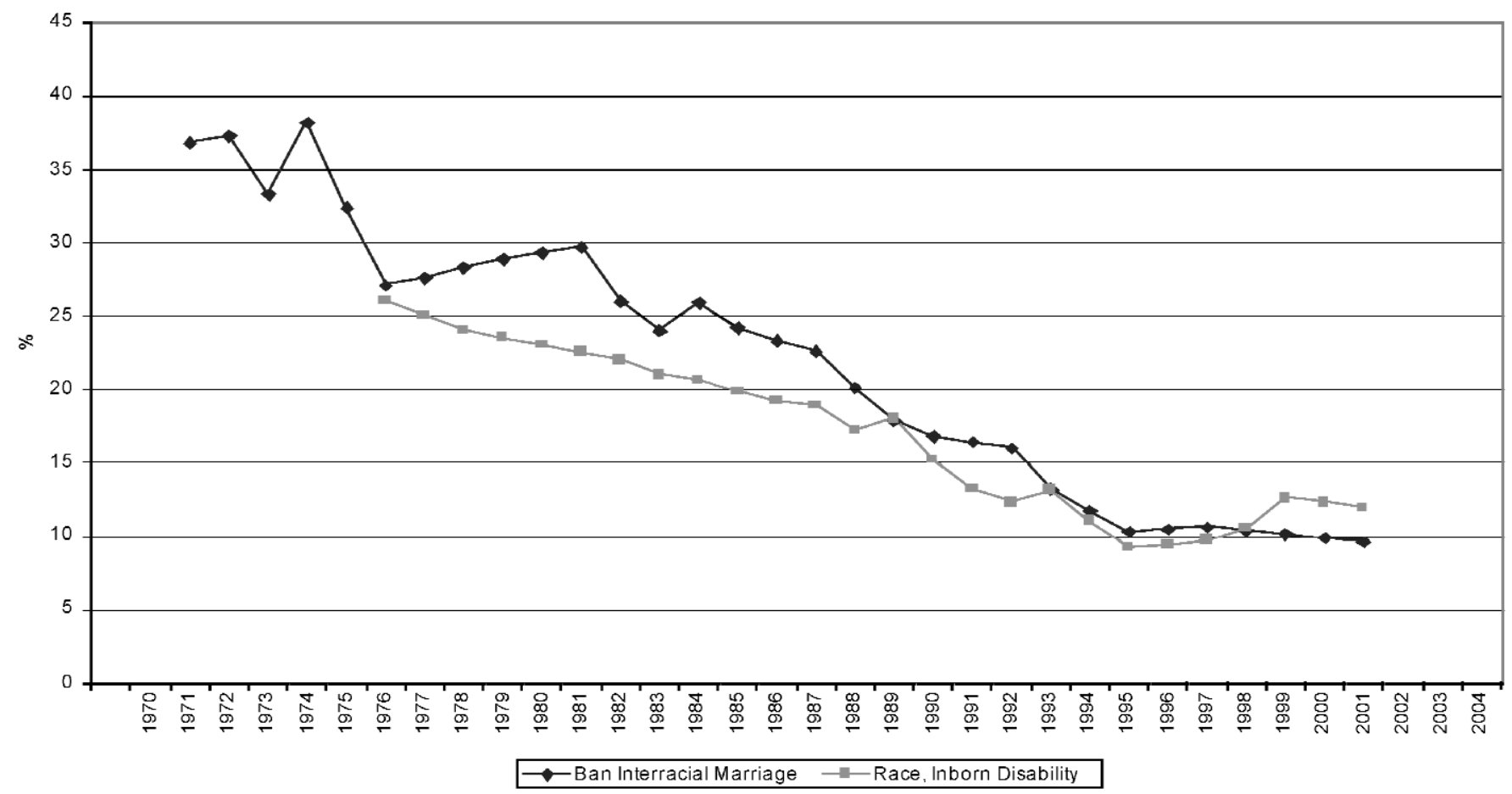

Notes: data are compiled by the authors from the General Social Survey. Data were imputed for years when questions were not asked. The survey questions were as follows: 1) "Do you think there should be laws against marriages between Blacks and whites? (yes/no)," 2) On average Blacks have worse jobs, income, and housing than white people. Do you think these differences are because most Blacks have less in-born ability to learn? (ycs/no)."

repeal of the state constitutional ban on miscegenation (Knigge and Moody 2003) and 13 states adopted constitutional bans on same-sex marriage during the 2004 elections. And, as noted, these opinions are strongly shaped by religious beliefs and adherence to those beliefs (Barlow and Probert 2004; Moran 2001; Schuman et al. 1997; Sherrill and Yang 2000; Westervelt 2001). However, the data in Figures 1 and 2 lead us to suspect attributions about the biological origins of behavior play an even larger role in shaping opinions on marriage policy. To understand this phenomenon more clearly we turn to attribution theory.

\section{Attribution Theory}

Attribution theory suggests that individuals develop causal theories to explain the world around them, including explanations of why people behave the way they do and why some people perform better in society than others (Fiske and Taylor 1991; Heider 1944, 1958). Observed behaviors are attributed to the person (internal or dispositional) or the environment (situational). The manner of response to behaviors generally depends on whether dispositional or situational attributions are made.

Weiner (1979, 1985) proposed an additional dimension, namely controllability. Whereas dispositional and situational factors refer to perceived causes of behavior, controllability has to do with whether the behavior is perceived as controllable or uncontrollable. The emphasis on controllability has been especially useful for analyses of causal attributions related to stigmatized groups. For instance, Crocker, Cornwell, and Major (1993) found that overweight women who believed their condition was controllable were more likely to perceive prejudicial responses regarding their stigma as warranted.
Similarly, DeJong (1980) discovered that evaluations of obese people are more negative when their obesity is attributed to voluntary overeating as opposed to a psychological malady. More generally Weiner, Perry, and Magnusson (1988) established that stigmas with a behavioral origin such as child abuse, AIDS, and Vietnam War Syndrome were more likely attributed to controllable causes than stigmas with a physical basis such as Alzheimer's, heart disease, and cancer. Furthermore, in some cases attributing stigmas to a controllable cause elicited greater anger and negative affect toward the stigmatized.

Existing research has applied these principles to understanding the social stigma of homosexuality. Researchers hypothesized that people who considered homosexuality as a controllable state would report more negative attitudes toward homosexuals than those who viewed homosexuality as uncontrollable. Several studies have confirmed this, finding that people who viewed homosexuality as genetic or biologically based reported less negative attitudes about homosexuals (Aguero, Block, and Byrne 1984; Schneider and Lewis 1984; VanderStoep and Green 1988).

The theory suggests that a stigma perceived as controllable leads to more negative emotions and evaluations of the relevant group or individual. A genetic or biologically based attribution about the origins of homosexuality suggests people believe homosexuality is not controllable. However, a belief that homosexuality is acquired through social context, learned, or a personal preference suggests a belief that homosexuals can control this condition, and therefore can change their sexual orientation. If sexual orientation can be changed, then perhaps there is less of a need for public policies that protect individual orientations. Thus, the causal attribution individuals make should influence their support for same-sex marriage. 


\section{Origin of Homosexuality (Born with) and Support for Legal Same-Sex Marriage}

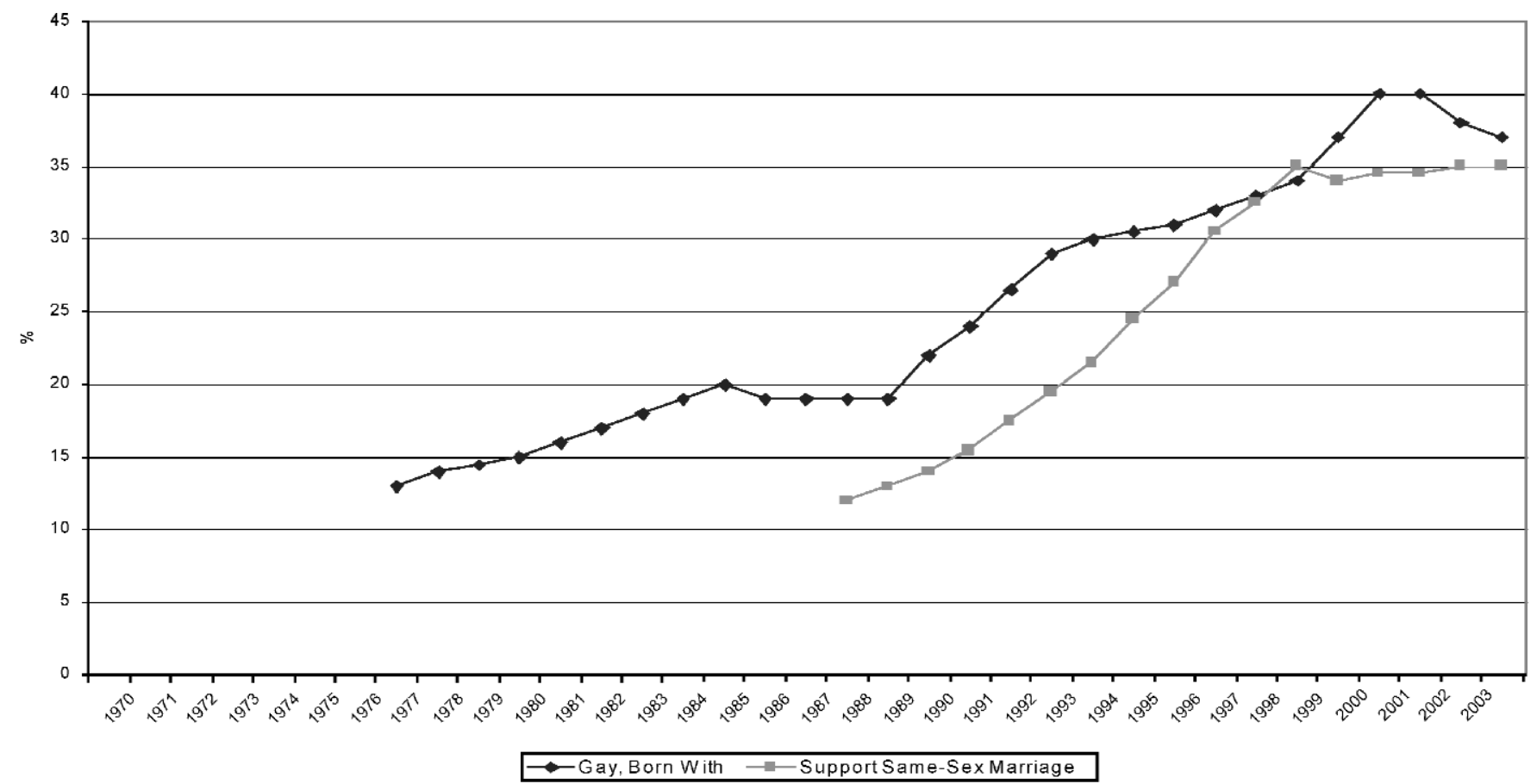

Notes: data are compiled by the authors from Gallup surveys. Data were imputed for years when questions were not asked. The survey questions were as follows: 1) "In your view, is homosexuality something a person is born with, or is homosexuality due to factors such as upbringing and environment? (born with/upbringing and environment/both)," and 2) "Do you think marriages between homosexuals should or should not be recognized by the law as valid? (should/should not)."

We can apply the same theoretical lens to opinions about legal bans on interracial marriage. However, in this instance, an explicitly negative biologically based attribution, one also considered uncontrollable, we expect to lead to less support for African-American rights. In fact, Kinder and Mendelberg $(1995,406)$ refer to beliefs that blacks have lower social and economic achievement because of the "inadequacies of blacks themselves" as biologically based forms of prejudice, but do not couch their arguments in attribution theory (see also Nelson 1999). Using their language or formulations from attribution theory makes little difference. If individuals believe intelligence differs between races, and attribute these differences to biological, uncontrollable determinants such as in-born ability to learn or level of motivation, this attribution should in turn increase support for laws banning interracial marriage. Why support interracial marriage when it may produce offspring considered biologically inferior (Stoddard 2003)? This logic grows from distorted attributions linking perceived deficiencies in blacks to uncontrollable biological sources. To avoid spreading biological defects, individuals who report such attributions are far less likely to support interracial dating or marriage, and are likely to support legal bans on interracial marriage (Schuman et al. 1997). We then hypothesize that those individuals who attribute the relative poor position of blacks in American society to a biologically based defect, such as an innate inability to learn, will be more likely to support laws that ban interracial marriage.

\section{Data and Analysis}

For our model of opinion on same-sex marriage we use a question from a May 2004 Gallup survey of national adults. In that survey Gallup asked respondents: "Should homosexual marriages be recognized by the law as valid?" Almost $37 \%$ of respondents stated homosexual marriages should be valid, while $64 \%$ reported they should not be recognized.

Our central independent variable is taken from the question: "In your view, is homosexuality something a person is born with, or is homosexuality due to factors such as upbringing and environment?" Respondents were allowed to refuse these choices and indicate both or neither. We only use those respondents who indicated "born with" (42\%) or "upbringing/ environment" (45\%). These responses were coded " 0 " and " 1 ," respectively. Based on previous studies of attitudes on gayrelated policy we also included a number of control variables (Bowman et al. 2004; Brewer 2002, 2003a, 2003b, Pew Research Center 2003; Sherrill and Yang 2000). These include gender, marital status, having children, race, religiosity, income, education, political ideology, and partisanship. We expect that women, whites, the less religious, the wealthy, the highly educated, liberals, Democrats, those with no young children, and the unmarried will be more supportive of laws that recognize same-sex marriage (Brewer 2002, 2003a, 2003b, Sherrill and Yang 2000).

For our model of support for laws banning interracial marriage we use the following question from the General Social Survey 1972 to 2002 cumulative file: "Do you think there should be laws against marriages between (Negroes/ Blacks/African-Americans) and whites?" On average, over the 20 years the question was asked, approximately $77 \%$ of respondents reported there should not be and 23\% indicated there should be. As noted in Figure 1, the percentage of respondents saying "yes" has declined steadily over time.

The main independent variable is based on the question: "On average Blacks have worse jobs, income, and housing 


\begin{tabular}{|c|c|c|c|c|}
\hline Independent Variables & \multicolumn{2}{|c|}{$\begin{array}{c}\text { Opposition to } \\
\text { Same-Sex Marriage }\end{array}$} & \multicolumn{2}{|c|}{$\begin{array}{l}\text { Opposition to Law } \\
\text { Banning } \\
\text { Interracial Marriage }\end{array}$} \\
\hline $\begin{array}{l}\text { Attribution: Upbringing/ } \\
\text { Environment }\end{array}$ & $1.329(.210)$ & .000 & - & \\
\hline $\begin{array}{l}\text { Attribution: No in-born } \\
\text { Disability to learn }\end{array}$ & - & & $1.330(.078)$ & .000 \\
\hline Female & $-.429(.208)$ & .039 & $.004(.072)$ & .951 \\
\hline Age & $.034(.007)$ & .000 & $-.029(.002)$ & .000 \\
\hline Ideology: > liberal & $-.649(.138)$ & .000 & $.119(.028)$ & .000 \\
\hline Partisanship: > Democrat & $-.228(.068)$ & .001 & $.045(.018)$ & .011 \\
\hline Income & $.023(.088)$ & .796 & $.083(.013)$ & .000 \\
\hline Education & $-.251(.109)$ & .021 & $.615(.043)$ & .000 \\
\hline Constant & $4.328(.862)$ & .000 & $1.523(.325)$ & .000 \\
\hline Pseudo $R$-square & .43 & & .35 & \\
\hline Log Likelihood & 646.168 & & 5369.681 & \\
\hline Chi-Square & 262.999 & .000 & 1820.233 & .000 \\
\hline \multicolumn{5}{|l|}{$\%$ Correctly } \\
\hline Predicted & $77.1 \%$ & & $85.6 \%$ & \\
\hline Number of Cases & 695 & & 7686 & \\
\hline
\end{tabular}

Notes: Coefficients are logistic regression coefficients. Standard errors are in parenthesis. The dependent variables are based on the following survey questions: Gallup 1) "Do you think marriages between homosexuals should or should not be recognized by the law as valid? (should (1), should not (2))." GSS 2) "Do you think there should be laws against marriages between Blacks and whites? (yes (1), no (2)).

than white people. Do you think these differences are because most Blacks have less in-born ability to learn?" Those indicating yes are coded as " 0 " (16\%) and those indicating no are coded as " 1 " (84\%).

Based on previous studies of support for interracial marriage bans (Firebaugh and Davis 1988; Kinder and Mendelberg 1995; Knigge and Moody 2003; Quillian 1996; Schuman et al. 1997; Tenzer 1990; Wilson 1986; Yancey 2001), and previous studies of opposition to policies that benefit African Americans (Bobo and Kluegel 1993; Carmines and Layman 1998; Nelson 1999; Schuman et al. 1997), we also included a number of control variables for respondent characteristics. These include gender, race (not including African Americans because they were not asked the key questions), income, education, political ideology, partisanship, religiosity, and whether or not a respondent resided in the South. We expect that women, non-whites, the wealthy, the highly educated, liberals, Democrats, the less religious, those with no young children, the unmarried, and non-Southerners will be less supportive of laws against interracial marriage (Bobo and Kluegel 1993; Firebaugh and Davis 1988; Kinder and Mendelberg 1995; Quillian 1996; Schuman et al. 1997; Tenzer 1990; Wilson 1986).

\section{Results}

Table 1 displays the estimates from the logistic regressions models of opinion on legal recognition of same-sex marriage and legal bans on interracial marriage. Based on model fit statistics, both models perform reasonably well. Opposition to legal recognition of same-sex marriage is a function of being non-white, male, older, politically conservative, Republican, less educated, and more religious. In the interracial marriage model the control variables perform in a similar manner, with some differences. Again martial status and having young children is not statistically significant, but higher levels of income are associated with opposition to a ban. Interestingly, gender does not appear to shape opinion on this issue, though it was a strong predictor on same-sex marriage. And religiosity, which played a strong role in the same-sex marriage model, also plays a significant role here; highly religious individuals are more likely to oppose both same-sex marriage and interracial marriage. This finding makes sense in light of the fact that most religious traditions have narrow views of the traditional family and the types of relationships that should be sanctioned (Cott 2000; Ellison 2004).

Most importantly, the estimates for the attribution variables were as hypothesized. In the same-sex marriage model, attributing homosexuality to upbringing or the environment significantly increases the probability that a respondent will oppose same-sex marriage. Attributing the cause of homosexuality to biology, or being born with it, however, significantly increases the probability that a respondent will support laws that recognize same-sex marriages. Among all variables, the largest marginal effects on the probability for support for same-sex marriage was attribution (.277), followed by race $(-.147)$, ideology (-.138), and religiosity (.120).

Similarly, respondents who espoused a negative causal attribution about race - that blacks have an in-born learning disability_were significantly more likely to support laws that ban 


\begin{tabular}{|c|c|c|c|c|c|c|}
\hline Independent Variables & \multicolumn{2}{|c|}{$\begin{array}{c}\text { Support for Legal } \\
\text { Same-Sex Relations }\end{array}$} & \multicolumn{2}{|c|}{$\begin{array}{l}\text { Opposition to } \\
\text { Civil Unions }\end{array}$} & \multicolumn{2}{|c|}{$\begin{array}{l}\text { Opposition to Constitutional } \\
\text { Amendment Banning } \\
\text { Same-Sex Marriage }\end{array}$} \\
\hline $\begin{array}{l}\text { Attribution: Upbringing/ } \\
\text { Environment }\end{array}$ & $-1.595(.201)$ & .000 & $1.461(.189)$ & .000 & $-.797(.185)$ & .000 \\
\hline White & $.558(.298)$ & .061 & $-.009(.280)$ & .975 & $.114(.275)$ & .678 \\
\hline Ideology: > liberal & $.611(.135)$ & .000 & $-.596(.128)$ & .000 & $.547(.122)$ & .000 \\
\hline Partisanship: > Democrat & $.043(.064)$ & .499 & $-.063(.061)$ & .297 & $.193(.059)$ & .001 \\
\hline Income & $.141(.086)$ & .100 & $.020(.082)$ & .803 & $.095(.079)$ & .228 \\
\hline Education & $.582(.110)$ & .000 & $-.287(.099)$ & .004 & $.199(.096)$ & .037 \\
\hline Religiosity: > less & $.500(.145)$ & .001 & $-.448(.138)$ & .001 & $.252(.128)$ & .048 \\
\hline Log Likelihood & 689.566 & & 745.241 & & 787.311 & \\
\hline Chi-Square & 257.680 & .000 & 213.524 & .000 & 167.625 & .000 \\
\hline \multicolumn{7}{|l|}{$\%$ Correctly } \\
\hline Predicted & $75.4 \%$ & & $73.2 \%$ & & $71.6 \%$ & \\
\hline Number of Cases & 690 & & 694 & & 698 & \\
\hline
\end{tabular}

Notes: Coefficients are logistic regression coefficients. Standard errors are in parenthesis. The dependent variables are based on the following survey questions: 1) "Should homosexual relations between consenting adults be legal (2) or illegal (1); 2) "Do you favor (1) or oppose (2) a law to allow homosexuals to form civil unions?" 3) Do you favor (1) or oppose (2) a constitutional amendment defining marriage as between a man and a woman?"

interracial marriage. Once more the marginal effects of this attribution surpassed that of any other conventional political variable in our model (.127). Though much discussion centers on organized religion and its powerful influence on marriage policies, the effects of causal attributions are considerably larger and deserve greater scrutiny.

\section{Discussion and Additional Analysis}

Our results strongly endorse the contention that biologically based attributions influence opinions concerning the regulation of marriage. However, the regulation of marriage, as it pertains to same-sex couples, involves more than simply support or opposition to the legal recognition of same-sex marriage (Barlow and Probert 2004). Indeed, levels of public support for gay relationships vary considerably depending on pollsters' questions and specific question wording (Sherrill and Yang 2000). The issue has several dimensions with varying degrees of public support, including the legality of homosexual relations between consenting adults, laws that ban same-sex marriage, including constitutional bans on same-sex marriage, and civil unions-a non-religious option to marriage being practiced in Vermont and under consideration in several other states (Barlow and Probert 2004; Dupuis 2002). Although a majority of Americans oppose same-sex marriage (55\%), only a bare majority supports a constitutional ban on same-sex marriage (51\%), a minority believes that homosexual relations should be illegal $(44 \%)$, and the public is split on the legal recognition of civil unions (49 to 48\%) (Moore and Carroll 2004). To confirm that our findings are applicable to the regulation of homosexual relationships broadly conceived, we also model opinion on these other issues. The results are displayed in Table 2.

The logistic regression estimates are consistent with prior models in Table 1. Although some of the variables, such as partisanship, gender, race, and income do not appear to influence the likelihood of opposing or supporting these policies, key forces, such as ideology, religiosity, and education play a significant role. More importantly, attributions concerning the origin of homosexuality significantly influence the probability of opposing or supporting each of these policies. This set of findings confirms our earlier analysis and suggests that our arguments concerning causal attributions to biology are key determinants for understanding individual policy preference on marriage as well as relationships more generally conceived.

\section{Conclusions}

In this article we examined how biologically based attributions influenced preferences toward government regulation of marriage and relationships. We argued that these causal attributions powerfully influence individual policy preferences, especially on issues that may elicit a dimension in human biology. Based on this unique study we draw several important conclusions.

First, the connection between biological attributions about blacks and homosexuals and marriage rights for these groups is very apparent and recently appears to have increased in strength. In particular, even as fewer Americans attribute biological causes to the lower socio-economic status of blacks and fewer Americans support bans on interracial marriages, individual beliefs that blacks have in-born learning disabilities strongly correlate with support for bans on interracial 
marriage. Conversely, the percentage of Americans believing that homosexuality is innate has steadily increased, as has support for legal recognition of same-sex marriage. And, as was the case for blacks, the biologically based attribution is strongly correlated with opinion on gay marriage.

Second, individual-level multivariate analyses confirmed the observed aggregate associations. Independent of other important predictors, biologically based attributions were strong predictors of support for relevant marriage policies. Negative attributions about blacks' learning abilities significantly increased the probability of support for bans on interracial marriage. While this finding adds another case to attribution theory, it also fits well with previous research on racial prejudices and their role in shaping policy preferences.

Third, multivariate analyses also demonstrated the powerful role of biological attributions about homosexuality and support for same-sex marriage. Individuals who do not attribute homosexuality to biological origins, and instead believe that homosexuality is a result of upbringing or the environment, are far less likely to support the legal recognition of same-sex marriages. Our analysis of discrete change across independent variables indicates that causal attributions have the greatest impact on support for recognition of same-sex marriage. Given that trends show Americans increasingly believe homosexuality has a biological component, and the demonstrated

\section{References}

Barlow, Anne, and Rebecca Probert. 2004. "Regulating Marriage and Cohabitation: Changing Family Values and Policies in Europe and North America-An Introductory Critique." Law \& Policy 26(1):1-11.

Bittles, Alan H., and James V Neel. 1994. "The Costs of Human Inbreeding and Their Implications for Variation at the DNA Level." Nature Genetics 8(1):117-121.

Bobo, Lawrence, and James R. Kluegel. 1993. "Opposition to RaceTargeting: Self Interest, Stratification Ideology, or Racial Attitudes?" American Sociological Review 58(2):443-464.

Bowman, Karlyn, and Bryan O'Keefe. 2004. Attitudes about Homosexuality and Gay Marriage. Washington, D.C.: American Enterprise Institute.

Bratt, Carolyn S. 1984. "Incest Statutes and the Fundamental Right of Marriage: Is Oedipus Free to Marry?" Family Law Quarterly 18(2):257-309.

Brewer, Paul R. 2003a. "The Shifting Foundations of Public Opinion about Gay Rights." Journal of Politics 65(4):1208-1220. . 2003b. "Values, Political Knowledge, and Public Opinion about Gay Rights.” Public Opinion Quarterly 67(2):173-201. . 2002. "Framing, Value Words, and Citizens' Explanations of Their Issue Opinions." Political Communication 19(3):303-316.

Carmines, Edward G., and Geoffrey C. Layman. 1998. "When Prejudice Matters: The Impact of Racial Stereotypes on the Racial Policy Preferences of Democrats And Republicans." In Perception and Prejudice: Race and Politics in the United States, eds. Jon Hurwitz and Mark Peffley. New Haven, CT: Yale University Press.

Cott, Nancy F. 2000. Public Vows: A History of Marriage and the Nation. Cambridge: Harvard University Press.

Crocker, J., B. Cornwell, and B. Major. 1993. "The Stigma of Overweight: Affective Consequences of Attributional Ambiguity. Journal of Personality and Social Psychology 64:60-70.

Cruz, David B. 2003. "Should Same-Sex Marriage Be Legal? Yes." Focus on Law Studies 29(1):4, 7.

DeJong, W. 1980. The Stigma of Obesity: The Consequences of Naïve Assumptions Concerning the Causes of Physical Deviance. Journal of Health and Social Behavior 21:75-87.

Dupuis, Martin. 2002. Same-Sex Marriage, Legal Mobilization, and the Politics of Rights. New York: Peter Lang.

Ellison, Marvin Mahan. 2004. Same Sex Marriage: A Christian Ethical Analysis. Berea, OH: Pilgrim Press.

Firebaugh, Glenn, and Kenneth E. Davis. 1988. "Trends in Antiblack Prejudice, 1972-1984: Region and Cohort Effects." American Journal of Sociology 94(2):251-72. effect this attribution has on support for same-sex marriage, the future appears reasonably bright for legal recognition of same-sex marriage and civil unions. Gays and lesbians clearly faced significant setbacks in the 2004 elections, but opinion and attribution trends suggest a speed bump more than definitive reversal.

Fourth, our findings were supported and expanded through additional examination of public opinion on support for legalization of same-sex relations, a constitutional ban on same-sex marriage, and civil unions for homosexual couples. It is thus clear that causal attributions shape a variety of opinions related to homosexuality and homosexual relationships. This suggests the approach taken here can be generalized to a variety of gay civil rights issues and have significant implications for proponents and opponents of gay civil rights.

Finally, in light of the historical understanding of marriage as the foundation of the family, and the apparent influence of biological understandings embedded in existing laws regulating marriage, perhaps our findings are not terribly surprising. However, historical wisdom need not drive opinions and, in fact, political contestation over biological attributions may change the prevailing attribution and thus preferences on marriage regulation. In sum, the forces that shape individual attributions are paramount in understanding future changes in policy preferences.
Fiske, Susan T., and Shelley E. Taylor. 1991. Social Cognition. Boston: McGraw-Hill.

Heider, Fritz. 1944. "Social Perception and Phenomenal Causality." Psychological Review 51:358-374.

. 1958. The Psychology of Interpersonal Relations. New York: Wiley. Kinder, Donald R., and Tali Mendelberg. 1995. "Cracks in American Apartheid: The Political Impact of Prejudice among Desegregated Whites." Journal of Politics 57(2):402-24.

Knigge, Pia, and Bradley Moody. 2003. "The 2000 'Anti-Miscegenation' Vote In Alabama: Is the 'Old South' Really that Old?' Presented at the Annual Meeting of the Midwest Political Science Association, Chicago.

Kuklinski, James H., and Michael David Cobb. 1998. "When White Southerners Converse about Race." In Perception and Prejudice: Race and Politics in the United States, eds. Jon Hurwitz and Mark Peffley. New Haven, CT: Yale University Press.

Micklos, David, and Elof Carlson. 2000. "Engineering American Society: The Lesson of Eugenics." Nature Reviews Genetics 1 (November): 153-158.

Moore, David W., and Joseph Carroll. 2004. "Support for Gay Marriage/Civil Unions Edges Upward." Gallup News Service, 17 May.

Moran, Rachel. 2001. Interracial Intimacy: The Regulation of Race and Romance. Chicago: University of Chicago Press.

Nelson, Thomas E. 1999. "Group Affect and Attribution in Social Policy Opinion." Journal of Politics 61(2):331-62.

Ottenheimer, Martin. 1990. "Lewis Henry Morgan and the Prohibition of Cousin Marriage in the United States." Journal of Family History 15(3):325-334.

Pew Research Center for the People and the Press. 2003. Republicans Unified, Democrats Split on Gay Marriage: Religious Beliefs Underpin Opposition to Homosexuality. Washington, D.C.: The Pew Research Center for the People and the Press.

Quillian, Lincoln. 1996. "Group Threat and Regional Change in Attitudes toward African-Americans." American Journal of Sociology 102(3):816-860.

St. Jean, Yanick. 1998. "Let People Speak for Themselves: Interracial Unions and the General Social Survey." Journal of Black Studies 28(3):398-414.

Schuman, Howard, Charlotte Steeh, and Lawrence Bobo. 1997. Racial Attitudes in America: Trends and Interpretations. Cambridge: Harvard University Press.

Scott, Elizabeth S. 2000. "Social Norms and the Legal Regulation of Marriage.” Virginia Law Review 86(8):1901-1970.

Sherrill, Kenneth, and Alan Yang. 2000. "From Outlaws to In-Laws: AntiGay Attitudes Thaw." Public Perspective 11(1):20-31. 
Smith, Raymond A., and Donald P. Haider-Markel. 2002. Gay and Lesbian Americans and Political Participation. Denver: ABC-CLIO Publishers.

Stoddard, Lothrop. 2003. Reprint. The Rising Tide of Color Against White World Supremacy. Honolulu: University Press of Hawaii.

Strasser, Mark. 2002. On Same-Sex Marriage, Civil Unions, and the Rule of Law: Constitutional Interpretation at the Crossroads. Westport, CT: Praeger.

Tenzer, Lawrence R. 1990. A Completely New Look at Interracial Sexuality: Public Opinion and Select Commentaries. Manahawkin, NJ: Scholars' Publishing House.

Yancey, George A. 2001. "An Analysis of Resistance to Racial Exogamy: The 1998 South Carolina Referendum." Journal of Black Studies 31:635-51.

Yang, Alan S. 1999. From Wrongs to Rights: Public Opinion on Gay and Lesbian Americans Moves toward Equality, 1973-1999. Washington,

D.C.: National Gay and Lesbian Task Force.
Weiner, Bernard. 1985. "An Attribution Theory of Achievement, Motivation, and Emotion. Psychological Review 92:548-573.

. 1979. "A Theory of Motivation for Some Classroom Experience." Journal of Educational Psychology 71:3-25.

Weiner, Bernard, Raymond Perry, and Jamie Magnusson. 1988. "An Attributional Analysis of Reactions to Stigmas." Journal of Personality and Social Psychology 55:738-748.

Westervelt, Don. 2001. "National Identity and the Defense of Marriage." Constellations 8(1):106-126.

Wilson, Thomas C. 1986. "Interregional Migration and Racial Attitudes." Social Forces 65(1):177-186.

Wood, Peter B., and John P. Bartkowski. 2004. "Attribution Style and Public Policy Attitudes toward Gay Rights." Social Science Quarterly 85(1):58-74. 


\section{AMERICAN PRLITICAL SCIENCE ASSRCIATION}

\section{APSA Minority Identification (MID) Project}

In 1989, APSA established the Minority Identification (MID) Project as part of its efforts to diversify the political science profession. A collaboration of undergraduate and graduate political science departments, the MID Project seeks to identify talented undergraduate minorities interested in being recruited to doctoral programs. The program complements the important efforts already made through the Ralph Bunche Summer Institute and Minority Fellows Program.

\section{HOW IT WORKS}

APSA maintains an on-line database of African-American, Latino/a, NativeAmerican, and Asian-American undergraduates who have been identified as possible candidates for graduate study in political science. Undergraduate departments can identify students, or undergraduate students themselves can request that their advisor submit their names to the database. Recruiters from the nation's top graduate political science programs have unlimited access to this database and actively recruit listed students.

\section{MID LIST-SERV}

In an effort to enhance the project, APSA has created a list-serv for students in the MID database to discuss issues related to graduate education with students currently in graduate programs and political science faculty. Representatives at each participating program have agreed to serve as "virtual mentors" to help MID students with general questions about the graduate school experience as well as specific questions about their department's program. APSA also uses this tool throughout the year to disseminate helpful information about the graduate application process to students in the MID database.

\section{HOW TO PARTICIPATE}

Interested minority students should contact their undergraduate advisor and ask that their name be submitted to the MID database. Department faculty should identify promising minority students and submit those interested in a graduate education in political science to APSA via their Departmental Services Program (DSP) on-line account. Include each student's name, contact information, email address, major, GPA, and areas of interest. Any institution with a DSP membership has the ability to submit students to the database.

\section{Participating Graduate Programs}

- American University

- Brown University

- University of California, Berkeley Irvine Los Angeles San Diego

- University of Chicago

- Colorado State University

- University of Colorado, Boulder

- Columbia University

- Cornell University

- Duke University

- Emory University

- George Washington University

- Georgia State University

- Harvard University

- University of Illinois, Chicago

- University of Illinois, Urbana/ Champaign

- Indiana University

- University of lowa

- University of Maryland

- University of Massachusetts, Amherst

- MIT

- Miami University

- Michigan State University

- University of Michigan

- University of Minnesota
- University of Missouri, Columbia

- University of New Mexico

- University of New Orleans

- New School University

- New York University

- University of North Carolina, Chapel Hill

- Northwestern University

- Ohio State University

- University of Oregon

- University of Pennsylvania

- Pennsylvania State University

- Princeton University

- Purdue University

- University of Rochester

- Rutgers University

- University of South Carolina

- University of Southern California

- Syracuse University

- University of Texas, Austin

- Texas A\&M University

- Vanderbilt University

- University of Washington, Seattle

- Washington State University

- University of Wisconsin, Madison

- Yale University
- University of Virginia

\section{American FOR MORE INFORMATION Political Science Association

